\title{
System of Corporate Social and Environmental Responsibility Indicators of Enterprises for Managerial Decision-Making Taking the Needs of Stakeholders into Account ${ }^{*}$
}

\author{
Denys O. SMolennikovi, Yulija V. Chortok ${ }^{i i}$, Anatolit V. Bondar ${ }^{i i i}$
}

\begin{abstract}
In today's conditions of globalization, any advantages are important for every company in the competition for the consumer. One of them is the implementation of measures for social and environmental corporate responsibility of enterprises and taking into account its practice in forming the company's development strategy. The research examines the decision-making about implementation of corporate social and environmental responsibility in enterprises. Nowadays doing business on the principles of social and environmental responsibility is not only following current trends, but also an important component of the strategy to respond to new challenges.

The set of measures and projects implemented by enterprises to protect the environment and improve the quality of life of the population is usually demanded and has a positive effect on the image of enterprises. At the same time, these actions do not always meet the real needs of stakeholders. There is a need to take into account the interests of stakeholders that became the basis for the idea to develop a simple and user-friendly system of corporate social and environmental responsibility indicators. The purpose of the paper is to form scientific and methodological approaches to defining corporate social and environmental responsibility indicators, which take into account the needs of major groups of stakeholders, and form a common vision towards formulating enterprise development strategy and contribute to effective managerial decision-making in solving social, economic and environmental issues. As a result of the study, a computer program CSLinked was developed, which allows to analyze indicators of enterprises social and environmental corporate responsibility taking into account the needs of stakeholders and provides selfassessment of the company in three groups of indicators - economic, social and environmental.
\end{abstract}

Keywords: corporate social and environmental responsibility, indicator, managerial decision-making, enterprise, stakeholders, strategy.

Introduction. Corporate social and environmental responsibility (CSER) has radically transformed the business structures of the twenty-first century in the way they conduct their business practices and function in the social environment. Issues that did not matter a few decades ago are now the main ones that should be included in the corporate management strategies of the leading companies in our world today, regardless of the level of profitability and size of the entity.

${ }^{i i}$ Denys O. Smolennikov, C.Sc. (Economics), Associate Professor, Department of Management, Sumy State University;

iii Yuliia V. Chortok, C.Sc. (Economics), Associate Professor, Department of Economics, Entrepreneurship and Business-Administration, Sumy State University;

${ }^{i v}$ Anatolii V. Bondar, PhD student, Department of Management, Sumy State University.

* The material is prepared according to the research work "Corporate Social and Environmental Responsibility for Sustainable Development: Stakeholders Partnership in the Real, Financial and Public Sectors of the Economy", which is funded by the Grant from the Ministry of Education and Science of Ukraine (No of state registration 0117U003933);

(C) D. O. Smolennikov, Yu. V. Chortok, A. V. Bondar, 2020.

https://doi.org/10.21272/mer.2020.88.14

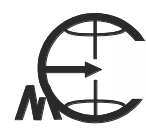


Over the past few years, many leading companies around the world have set themselves the goal of creating CSER values and have begun to incorporate not only economic but also social and environmental ideas into their corporate strategies.

The pace of CSER implementation in enterprises depends on several factors, among which a significant share is formed by stakeholders. The authors of the scientific work [1] to the decisions of CSER in relation to stakeholders include the following:

- solutions that promote community health;

- security solutions;

- solutions that improve education;

- solutions that improve employment;

- solutions that improve the quality of life in the natural environment;

- solutions that promote community and economic development;

- solutions that help meet basic human needs and desires.

These above-mentioned decisions are subject to the internal or external actions of the CSER in relation to internal and external stakeholders, which have a huge impact on their success or failure in the market, and community attitudes. It is interesting that the laws of economics are manifested, which is as follows: the more business contributes to meeting the needs of social life, solving economic and environmental problems, the more society will demand from business. In turn, stakeholders such as shareholders, employees or lenders want the business to continue to thrive and benefit from it.

Problem statement. The scientific works of G. Bowen [2], K. Davis [3], A. Carroll [4] and others became the basis for the formation of the scientific concept of CSER and were devoted to justifying the need for a responsible attitude of business to society and the environment.

Among Ukrainian scientists who have studied this issue in the context of the analysis of sustainable development problems, it is necessary to mention L. Korniychuk and V. Shevchuk [5], I. Makarenko and others. [6], I. Sotnyk [7] and others.

In our previous work on the development of the concept of CSER we paid much attention to the development of cooperation between communities and business $[8,9]$, taking into account the views of stakeholders in the formation of local infrastructure [10], identified key areas for stakeholders $[11,12]$, confirmed that an effective mechanism for the implementation of CSER enterprise is to take into account its practice in the formation of competitive strategy [13, 14].

However, a review of the scientific literature on the selected topic showed that the applied aspects of management decisions to establish effective cooperation between the company and stakeholders remain out of the attention of scientists and are insufficiently studied.

The purpose is to form scientific and methodological approaches to determining the system of indicators CSER of the enterprise, taking into account the needs of its main groups of stakeholders, and forms a common vision on the way to formulating enterprise development strategy and effective management decisions in solving social, economic and environmental problems.

Results of the research. Nowadays, being socially responsible is what is expected of all organizations, regardless of where they are based and what they do.

The introduction of social and environmental responsibility must begin with the top managers of the organization, because they must believe in the concept of CSER and the results of its implementation.

Assessment of any object of corporate social and environmental responsibility by any method, according to the author [15] requires the use of a certain system of indicators. There 
Denys O. Smolennikov, Yulija V. Chortok, Anatolii V. Bondar. System of Corporate Social and Environmental Responsibility Indicators of Enterprises for Managerial Decision-Making Taking the Needs of Stakeholders into Account

are partial and general, qualitative and quantitative, internal and external indicators of CSER evaluation.

According to the author of the scientific work [15], the main requirements for CSER indicators are the following:

- efficiency and convenience for management;

- compliance with CSER objectives;

- taking into account the criteria of international standards and industry specifics.

To assess the effectiveness of CSER, various methods are proposed that analyze the socially responsible measures of enterprises using different indicators. The most common are methods of assessing the effectiveness of socially responsible programs of the enterprise, which include a set of quantitative and qualitative indicators that characterize:

- availability and conditions of the enterprise regulatory documents (employment contracts, charter, insurance contracts, etc.);

- working conditions of employees (salary, social benefits, labor protection and safety, support of social programs, etc.);

- environmental factors (energy saving programs, environmental policy, measures to reduce the eco-destructive impact on the environment, etc.).

The authors propose a system of CSER indicators, conditionally divided into three groups economic, social and environmental (Table 1).

System of indicators CSER for management decisions

Table 1

\begin{tabular}{|c|l|c|c|}
\hline Cipher & \multicolumn{1}{|c|}{ The title of the indicator } & $\begin{array}{c}\text { Quantitative (QN)/ } \\
\text { qualitative (QL) }\end{array}$ & $\begin{array}{c}\text { Stimulator / } \\
\text { Distimulator }\end{array}$ \\
\hline 1 & \multicolumn{1}{|c|}{2} & 3 & 4 \\
\hline \multicolumn{3}{|c|}{ Economic } & QL \\
\hline IEH01 & Production of quality and innovative products & QL & $\mathrm{S}$ \\
\hline IEH02 & $\begin{array}{l}\text { Compliance with the rules and regulations of economic } \\
\text { activity }\end{array}$ & QL & $\mathrm{S}$ \\
\hline IEH03 & $\begin{array}{l}\text { The company has implemented anti-corruption } \\
\text { measures }\end{array}$ & $\mathrm{QN}$ & $\mathrm{S}$ \\
\hline IEH04 & $\begin{array}{l}\text { Increased costs for the prevention of accidents, diseases } \\
\text { (compared to the previous period) }\end{array}$ & $\begin{array}{l}\text { QN } \\
\text { Increased costs for overcoming the consequences of } \\
\text { pollution, accidents, etc. (compared to the previous } \\
\text { period) }\end{array}$ & $\mathrm{QL}$ \\
\hline IEH06 & $\begin{array}{l}\text { Availability and implementation of corporate } \\
\text { documents on ethics, good faith business }\end{array}$ & $\mathrm{S}$ \\
\hline IEH07 & Transparency of corporate governance & $\mathrm{QL}$ & $\mathrm{S}$ \\
\hline IEH08 & Disclosure of information on procurement plans & $\mathrm{QL}$ & $\mathrm{S}$ \\
\hline
\end{tabular}


Д. О. Смоленніков, Ю. В. Чорток, А. В. Бондар.

Система індикаторів корпоративної соціально-екологічної відповідальності

підприсмств для прийняття управлінських рішень із урахуванням потреб стейкхолдерів

Продовження табл. 1

\begin{tabular}{|c|c|c|c|}
\hline 1 & 2 & 3 & 4 \\
\hline IEH09 & Publication of financial statements on the site & $\mathrm{QL}$ & $\mathrm{S}$ \\
\hline IEH10 & $\begin{array}{l}\text { Increase in investment in enterprise development (compared to the } \\
\text { previous period) }\end{array}$ & QN & $\mathrm{S}$ \\
\hline IEH11 & Increase in taxes paid (compared to the previous period) & QN & $\mathrm{S}$ \\
\hline \multicolumn{4}{|c|}{ Social } \\
\hline ІСЦ01 & Clear and transparent system of employee bonuses & QL & $\mathrm{S}$ \\
\hline ІСЦ02 & An effective system of staff training & QL & $\mathrm{S}$ \\
\hline ІСЦ03 & The company is taking steps to ensure gender equality & QL & $\mathrm{S}$ \\
\hline ІСЦ04 & $\begin{array}{l}\text { Increase in sponsorship and charitable assistance (compared to the } \\
\text { previous period) }\end{array}$ & QN & $\mathrm{S}$ \\
\hline ІСЦ05 & Publication of information about vacancies on the official website & $\mathrm{QL}$ & $\mathrm{S}$ \\
\hline ІСЦ06 & $\begin{array}{l}\text { The company's development strategy provides for social } \\
\text { responsibility }\end{array}$ & QL & $\mathrm{S}$ \\
\hline ІСЦ07 & $\begin{array}{l}\text { Improving the level of security at the enterprise (compared to the } \\
\text { previous period) }\end{array}$ & QN & $\mathrm{S}$ \\
\hline ІСЦ08 & $\begin{array}{l}\text { Increase in wages and social guarantees (compared to the previous } \\
\text { period) }\end{array}$ & QN & $\mathrm{S}$ \\
\hline ІСЦ09 & $\begin{array}{l}\text { Increased funding for social projects in the region (compared to the } \\
\text { previous period) }\end{array}$ & QN & S \\
\hline ІСЦ10 & $\begin{array}{l}\text { The company's participation in raising social living standards in the } \\
\text { region }\end{array}$ & QL & S \\
\hline ІСЦ11 & $\begin{array}{l}\text { Increased research and development costs (compared to the } \\
\text { previous period) }\end{array}$ & QN & $\mathrm{S}$ \\
\hline \multicolumn{4}{|c|}{ Ecological } \\
\hline ІЕЛ01 & $\begin{array}{l}\text { Reduction of greenhouse gas emissions (compared to the previous } \\
\text { period) }\end{array}$ & QN & $\mathrm{S}$ \\
\hline ІЕЛ02 & $\begin{array}{l}\text { Availability of corporate documents to assist the region in solving } \\
\text { environmental problems }\end{array}$ & QL & S \\
\hline ІЕЛ03 & Publication of information on environmental audit & $\mathrm{QL}$ & $\mathrm{S}$ \\
\hline ІЕЛ04 & $\begin{array}{l}\text { Reduction of resource use, dematerialization (compared to the } \\
\text { previous period) }\end{array}$ & QN & $\mathrm{S}$ \\
\hline ІЕЛ05 & $\begin{array}{l}\text { Reduction of waste generation and the degree of their danger to the } \\
\text { environment (compared to the previous period) }\end{array}$ & QN & $\mathrm{S}$ \\
\hline ІЕЛ06 & $\begin{array}{l}\text { Reducing the volume of wastewater formation and reducing the } \\
\text { concentration of pollutants in them (compared to the previous } \\
\text { period) }\end{array}$ & QN & $\mathrm{S}$ \\
\hline ІЕЛ07 & $\begin{array}{l}\text { Reduction of man-made impact on land resources (compared to the } \\
\text { previous period) }\end{array}$ & QN & $\mathrm{S}$ \\
\hline ІЕЛ08 & The activity of the enterprise is safe for the environment & QL & $\mathrm{S}$ \\
\hline ІЕЛ09 & Introduction of green technologies, ecological certification & QL & $\mathrm{S}$ \\
\hline ІЕЛ10 & Use of energy efficient technologies & QL & S \\
\hline ІЕЛ11 & $\begin{array}{l}\text { Increasing the share of renewable energy sources (compared to the } \\
\text { previous period) }\end{array}$ & QN & $\mathrm{S}$ \\
\hline
\end{tabular}

Each of the indicators presented in table 1 has two features:

1) quantitative and qualitative;

2) stimulant and destimulator. 
Denys O. Smolennikov, Yulija V. Chortok, Anatolii V. Bondar. System of Corporate Social and Environmental Responsibility Indicators of Enterprises for Managerial Decision-Making Taking the Needs of Stakeholders into Account

Most indicators are stimulating, their growth is assessed in the information system as a positive practice of the enterprise.

(Table 2):

The needs of stakeholders are analyzed in terms of three main stakeholder groups

1) employees of the enterprise;

2) community;

3) consumers of products.

Table 2

The needs of the main groups of stakeholders in terms of CSER components

\begin{tabular}{|c|c|c|}
\hline Cipher & The needs of stakeholders & $\begin{array}{c}\text { Quantitative } \\
\text { (QN)/ } \\
\text { qualitative } \\
\text { (QL) }\end{array}$ \\
\hline \multicolumn{3}{|c|}{ Employees of enterprises } \\
\hline$\Pi 01$ & Decent and fair pay & QL \\
\hline$\Pi 02$ & Advanced training and the opportunity to manage career development & QL \\
\hline П03 & Confidence in the workplace & QL \\
\hline П04 & Availability and effectiveness of the employee's social package & QL \\
\hline$\Pi$ П05 & Involvement of employees in management decisions & QL \\
\hline$\Pi 06$ & Satisfaction with the moral and psychological climate & QL \\
\hline$\Pi 07$ & Pride for the company they work for & QL \\
\hline$\Pi 08$ & Work in safe conditions & QL \\
\hline$\Pi 09$ & Raising environmental awareness and culture among employees & QL \\
\hline$\Pi 10$ & $\begin{array}{l}\text { Opportunity to be involved in the implementation of social and } \\
\text { environmental projects }\end{array}$ & QL \\
\hline \multicolumn{3}{|c|}{ Community } \\
\hline$\Gamma 01$ & $\begin{array}{l}\text { Improvement of air purity in the region of residence (compared to the } \\
\text { previous period) }\end{array}$ & QN \\
\hline$\Gamma 02$ & Safe operation of the enterprise & QL \\
\hline$\Gamma 03$ & Satisfaction with the products of local producers (quantity, quality, etc.) & QL \\
\hline$\Gamma 04$ & $\begin{array}{l}\text { Increasing the number of implemented social and environmental projects in } \\
\text { the region (compared to the previous period) }\end{array}$ & QN \\
\hline$\Gamma 05$ & Transparency of enterprises in the region & QL \\
\hline$\Gamma 06$ & $\begin{array}{l}\text { Implementation of social and environmental projects by enterprises in the } \\
\text { region }\end{array}$ & QL \\
\hline$\Gamma 07$ & $\begin{array}{l}\text { Opportunity for employment at enterprises in the region, reducing } \\
\text { unemployment }\end{array}$ & QL \\
\hline \multicolumn{3}{|c|}{ Consumers of products } \\
\hline $\mathrm{C} 01$ & Consumption of safe products / obtaining safe service & QL \\
\hline $\mathrm{C} 02$ & Product innovation & QL \\
\hline $\mathrm{C} 03$ & Long history and reliability of the brand & QL \\
\hline $\mathrm{C} 04$ & Compliance with environmental standards & QL \\
\hline $\mathrm{C} 05$ & Opportunity to join a social project by consuming products & QL \\
\hline $\mathrm{C} 06$ & Consumption of products whose production does not harm the environment & QL \\
\hline $\mathrm{C} 07$ & Resource efficiency of products & QL \\
\hline
\end{tabular}


Д. О. Смоленніков, Ю. В. Чорток, А. В. Бондар.

Система індикаторів корпоративної соціально-екологічної відповідальності

підприсмств для прийняття управлінських рішень із урахуванням потреб стейкхолдерів

The ratio of CSER indicators and the needs of the main group of stakeholders are shown in table 3 .

Table 3

Matrix of compliance of CSER indicators of the enterprise to the interests of the main groups of stakeholders

\begin{tabular}{|c|c|c|c|c|c|c|c|c|c|c|c|c|c|c|c|c|c|c|c|c|c|c|c|c|}
\hline \multirow{2}{*}{ Cipher } & \multicolumn{10}{|c|}{ Interests of employees } & \multicolumn{7}{|c|}{ Interests of the community } & \multicolumn{7}{|c|}{ Interests of consumers } \\
\hline & $\Pi$ П01 & П02 & $\Pi 03$ & П04 & $\Pi 05$ & $\Pi 06$ & П07 & $\Pi 08$ & \begin{tabular}{|l|l|}
$\Pi 09$ \\
\end{tabular} & \begin{tabular}{|l|}
$\Pi 10$ \\
\end{tabular} & $\Gamma 01$ & $\Gamma 02$ & $\Gamma 03$ & $\Gamma 04$ & $\Gamma 05$ & $\Gamma 06$ & $\Gamma 07$ & $\mathrm{C} 01$ & $\mathrm{C} 02$ & $\mathrm{C} 03$ & $\mathrm{C} 04$ & $\mathrm{C} 05$ & $\mathrm{C06}$ & $\mathrm{C} 07$ \\
\hline IEH01 & & + & + & & & & + & & & & & & + & & & & & + & + & & & & & + \\
\hline IEH02 & + & & + & + & & + & + & + & & & & + & & & + & & + & + & & + & & & & \\
\hline IEH03 & + & & + & & + & + & + & & & & & & & & + & & & & & + & & & & \\
\hline IEH04 & & & + & & & & + & + & & & + & + & & & & & & & & & & & + & \\
\hline IEH05 & & & & & & & & + & & & + & + & & & & & & & & & & & + & \\
\hline IEH06 & & & + & + & + & + & + & & + & + & & & & & + & & & & & + & & & & \\
\hline IEH07 & & & + & & + & + & + & & & & & + & & & + & & & & & + & & & & \\
\hline IEH08 & & & + & & & & + & & & & & & + & & + & & + & & & & & & & \\
\hline IEH09 & + & & + & & & + & + & & & & & & & & + & & & & & + & & & & \\
\hline IEH10 & & + & + & & & & + & & & & & + & + & & & & & & & + & & & & \\
\hline IEH11 & & & + & & & & + & & & & & & & & + & & & & & & & & & \\
\hline ІСЦ01 & + & & & + & & + & + & & & & & & & & & & & & & & & & & \\
\hline ІСЦ02 & & + & & + & & + & + & & + & & & & & & & & & & & & & & & \\
\hline ІСЦ03 & + & & & + & & + & + & & & & & & & & & & & & & & & & & \\
\hline ІСЦ04 & & & & & & & + & & & + & & & & + & & + & & & & & & + & & \\
\hline ІСЦ05 & + & & & & & + & & & & & & & & & + & & + & & & & & & & \\
\hline ІСЦ06 & & & & + & & + & + & & & + & & & & + & + & + & & & & + & & + & & \\
\hline ІСЦ07 & & & + & + & & + & + & + & & & & + & & & & & & + & & & & & & \\
\hline ІСЦ08 & + & & & + & & + & + & & & & & & & & & & & & & & & & & \\
\hline ІСЦ09 & & & & & & & + & & & + & & & & + & & + & & & & & & + & & \\
\hline ІСЦ10 & & & & & & & + & & & + & & & & + & + & + & & & & & & & & \\
\hline ІСЦ11 & & + & + & & & & & & + & & + & + & & & & & & + & + & & & & & + \\
\hline ІЕЛ01 & & & & & & & + & + & & & + & + & & & & & & & & & + & & + & \\
\hline ІЕЛ02 & & & & & & & + & & & + & & + & & & + & & & & & & & + & + & \\
\hline ІЕЛ03 & & & + & & & + & + & + & + & & + & + & & & + & & & + & & & + & & + & \\
\hline ІЕЛ04 & & & + & & & & + & & & & + & + & & & & & & & & & + & & + & \\
\hline ІЕЛ05 & & & & & & & + & + & & & + & + & & & & & & & & & + & & + & \\
\hline ІЕЛ06 & & & & & & & + & + & & & & + & & & & & & & & & + & & + & \\
\hline ІЕЛ07 & & & & & & & + & + & & & & + & & & & & & & & & + & & + & \\
\hline ІЕЛ08 & & & + & + & & + & + & + & & & + & + & & & & & & & & & + & & + & \\
\hline ІЕЛ09 & & & + & & & & + & + & + & & + & + & + & & & & & + & + & & + & & + & + \\
\hline ІЕЛ10 & & & + & & & & + & & + & & + & + & & & & & & & + & & + & & + & \\
\hline ІЕЛ11 & & & & & & & + & & + & & + & + & & & & & & & & & + & & + & \\
\hline
\end{tabular}

Based on the above information, the authors developed a computer program CSLinked, which allows to analyze indicators of corporate social responsibility of enterprises taking into account the needs of stakeholders and provides self-assessment of the company in terms of three groups of indicators - economic, social and environmental. stakeholder groups - employees of the enterprise, community and consumers of products.

Conclusions and prospects of further research. Leading companies are expected to become more interested in CSER, which covers their areas of activity and affects their major stakeholders. The management of most companies is aware of the serious consequences of ignoring their responsibilities to stakeholders and the environment. The solution of these problems is possible under the condition of observance of the principle of innovation at 
Denys O. Smolennikov, Yulija V. Chortok, Anatolii V. Bondar. System of Corporate Social and Environmental Responsibility Indicators of Enterprises for Managerial Decision-Making Taking the Needs of Stakeholders into Account

formulation of strategies, acceptance of effective decisions at the decision of social, economic and ecological problems which the enterprises face.

\section{References}

1. Okpara, J. O. \& Idowu, S. O. (2013). Corporate Social Responsibility Challenges, Opportunities and Strategies for 21st Century Leaders. Springer-Verlag Berlin Heidelberg, 315 p.

2. Bowen, H. R. (1953). Social Responsibilities of the Businessman. Harper \& Row : N. Y.

3. Davis, K. (1960). Can business afford to ignore social responsibilities? California Management Review, № 2 (3), Vol. 2, P. 70-76.

4. Carroll, A. B. (1999). Corporate social responsibility: Evolution of definitional construct. Business and Society, № 38 (3), P. 268-295.

5. Kornijchuk, L. \& Shevchuk, V. (2009). Stalyj rozvytok i globalna misiya Ukrayiny [Sustainable development and global mission of Ukraine]. Ekonomika Ukrayiny. - № 4. - C. 4-13 [in Ukrainian].

6. Vasilieva, T .A., Lieonov, S. V., Makarenko, I. A. \& Sirkovska, N. (2017). Sustainability information disclosure as an instrument of marketing communication with stakeholders: markets, social and economic aspects. Marketing and Management of Innovation, 4, 350-357. http://doi.org/10.21272/mmi.2017.4-31

7. Sotnyk, I., Shvets, I., Momotiuk, L., \& Chortok, Y. (2018). Management of Renewable Energy Innovative Development in Ukrainian Households: Problems of Financial Support. Marketing and Management of Innovations, 4, 150-160. http://doi.org/10.21272/mmi.2018.4-14

8. Chortok, Yu. V. et al. (2019). Financial aspects of stakeholders cross-sector partnership in implementation of communities sustainable development projects. Financial and credit activity: problems of theory and practice, Vol. 3, No 30, 517-525. URL : http://fkd.org.ua/article/view/179927

9. Bondar, A. V. \& Smolennikov, D. O. (2016). Rozroblennja mehanizmu partnerstva vlady, biznesu ta gromady dlja realizacii' ekologo-orijentovanyh proektiv [Development of a mechanism of partnership between government, business and community for the implementation of environmentally friendly projects]. Visnyk of Sumy State University. Economy series, 4, 21-27. URL: http://nbuv.gov.ua/UJRN/VSU_ekon_2016_4_5 [in Ukrainian].

10. Chortok, Yu., Yevdokymova, A. \& Serpeninova, Yu. (2019). Formation of the mechanism of corporate social and environmental responsibility of the trading company. Journal of environmental management and tourism, Vol. 9, No. 5, 1011-1018. http://doi.org/10.14505//jemt.9.5(29).13

11. Chortok, Yu V., Makarenko, I. O. \& Serpeninova, Yu. S. (2017). Prozorist kompanij derzhavnogo sektoru Ukrayin` yak osnova zadovolennya informacijnyh potreb stejkxolderiv v umovax stalogo rozvytku. [Transparency of Ukrainian public sector companies as a basis for meeting the information needs of stakeholders in the context of sustainable development]. Mechanism of Economic Regulation, 4, 156-164 [in Ukrainian].

12. Smolennikov, D. O. \& Buriak, A. V. (2018). Specyfika informacijnyh zapytiv stejkholderiv u finansovomu sektori v umovah stalogo rozvytku [The specifics of information requests of stakeholders in the financial sector in terms of sustainable development]. Mechanism of Economic Regulation, 1, 53-61. http://doi.org/10.21272/mer.2018.79.04 [in Ukrainian].

13. Hakobyan, N., Khachatryan, A., Vardanyan, N., Chortok, Y., \& Starchenko, L. (2019). The implementation of corporate social and environmental responsibility practices into competitive strategy of the company. Marketing and Management of Innovations, 2, 42-51.

14. Smolennikov, D., \& Kostyuchenko, N. (2017). The role of stakeholders in implementing corporate social and environmental responsibility. Business Ethics and Leadership. Vol. 1, No. 1, pp. 55-62. http://doi.org/10.21272/bel.2017.1-07

15. Suhoterina, M. I. (2015). Mexanizm socialnoyi vidpovidalnosti u strategiyi korporatyvnogo upravlinnya mashynobudivnogo pidpryyemstva: Dysertaciya na zdobuttya naukovogo stupenya kandydata ekonomichnyh nauk. [The mechanism of social responsibility in the strategy of corporate governance of a machine-building enterprise: PhD thesis]. Odessa, 254 p. [in Ukrainian].

Manuscript received 27 February 2020 
Д. О. Смоленніков, Ю. В. Чорток, А. В. Бондар.

Система індикаторів корпоративної соціально-екологічної відповідальності

підприємств для прийняття управлінських рішень із урахуванням потреб стейкхолдерів

Система индикаторов корпоративной социально-экологической ответственности предприятий для принятия управленческих решений с учетом потребностей стейкхолдеров

\section{ДЕниС ОЛЕГович СмолЕнников", ЮЛИЯ ВЛАДИМИРОВНА ЧОРТОК ${ }^{* *}$ АНАТОЛИЙ ВАЛЕРИЕВИч БОНДАРВ ${ }^{* * *}$}

* кандидат экономических наук, доиент, доцент кафедры управления

Сумского государственного университета,

ул. Р.-Корсаковая, 2, г. Сумы, 40007, Украина,

тел.: 00-380-542-331261, e-mail: dos@management.sumdu.edu.ua

** кандидат экономических наук, дочент, доиент кафедры экономики, предпринимательства и бизнес-администрирования Сумского государственного университета, ул. Р.-Корсаковая, 2, г. Сумьл, 40007, Украина, тел.: 00-380-542-687918, e-mail: y.chortok@econ.sumdu.edu.ua

*** аспирант кафедры управления Сумского государственного университета, ул. Р.-Корсаковая, 2, г. Сумы, 40007, Украина, тел.:00-380-542-687878,e-mail: a.bondar@management.sumdu.edu.ua

В современных условиях развития глобализационных процессов любые преимущества имеют важное значение для каждой компании в конкурентной борьбе за потребителя. Одна из них реализация мероприятий социально-экологической корпоративной ответственности предприятий и учета ее практики при формировании стратегии развития компании. В исследовании рассматривается вопрос принятия управленческих решений касательно реализации корпоративной социально-экологической ответственности на предприятиях под влиянием заинтересованных сторон. Ведение хозяйственной деятельности на принципах корпоративной социальной и экологической ответственности на сегодняшний день является не только следованием современным трендам, но и важной составляющей стратегии реагирования на новые вызовы. Комплекс мероприятий и проектов, которые реализуют предприятия с целью охраны окружающей среды и улучшения качества жизни населения, как правило, является востребованным, и положительно влияет на имидж предприятий. В то же время, не всегда эти действия соответствуют реальным потребностям заинтересованных сторон. Именно необходимость учета интересов стейкхолдеров стала основой идеи для разработки простой и понятной для пользователей системы показателей корпоративной социально-экологической ответственности. Целью исследования стало формирование научно-методических подходов к определению индикаторов корпоративной социально-экологической ответственности, которые бы учитывали запросы основных групп стейкхолдеров, и формировали общее видение на пути к разработке стратегии развития предприятия и принятия эффективных управленческих решений при решении социальных, экономических и экологических проблем. В результате исследования была разработана компьютерная программа CSLinked, которая позволяет анализировать показатели корпоративной социальной ответственности предприятий с учетом потребностей заинтересованных сторон и дает самооценку компании по трем группам показателей - экономическим, социальным и экологическим.

Ключевые слова: корпоративная социально-экологическая ответственность, индикатор, принятие управленческих решений, предприятие, стейкхолдеры, стратегия.

Mechanism of Economic Regulation, 2020, No 2, 159-168 ISSN 1726-8699 (print) 
Denys O. Smolennikov, Yulija V. Chortok, Anatolii V. Bondar. System of Corporate Social and Environmental Responsibility Indicators of Enterprises for Managerial Decision-Making Taking the Needs of Stakeholders into Account

Система індикаторів корпоративної соціально-екологічної відповідальності підприємств для прийняття управлінських рішень із урахуванням потреб стейкхолдерів

\section{ДЕНИС ОЛЕГОВИч СМОЛЕНнгКов*, Юлья ВолодимиРІвнА ЧоРток**, АНАТОЛІй ВАЛЕРІйОВИч БонДАР***}

* кандидат економічних наук, доцент, дочент кафедри управління Навчально-наукового інституту фінансів, економіки та менеджменту імені Олега Балачького Сумського державного університету вул. Р.-Корсаковая, 2, м. Суми, 40007, Украӥна, тел.:00-380-542-331261,e-mail: dos@management.sumdu.edu.ua

** кандидат економічних наук, доцент, доиент кафедри економіки, підприємництва та бізнесадміністрування Сумського державного університету вул. Р.-Корсаковая, 2, м. Суми, 40007, Україна, тел.: 00-380-542-687918, e-mail: y.chortok@econ.sumdu.edu.ua

**** аспірант кафедри управління Сумського державного університету, вул. Р.-Корсаковая, 2, м. Суми, 40007, Україна,

тел.:00-380-542-687878, e-mail: a.bondar@management.sumdu.edu.ua

У сучасних умовах розвитку глобалізаційних процесів будь-які переваги мають важливе значення для кожної компанії в конкурентній боротьбі за споживача. Одна 3 них - реалізація заходів корпоративної соціально-екологічної відповідальності підприємств та врахування іiі практики при формуванні стратегії розвитку компанії. У дослідженні розглядається питання прийняття управлінських рішень щодо реалізації корпоративної соціально-екологічної відповідальності на підприємствах під впливом зацікавлених сторін. Ведення господарської діяльності на принципах соціальної та екологічної відповідальності на сьогоднішній день $\epsilon$ не тільки слідкуванням сучасним трендам, але й важливою складовою стратегії реагування на нові виклики. Комплекс заходів та проектів, які реалізують підприємства задля охорони довкілля та покращення якості життя населення, зазвичай, є затребуваним, та позитивно впливає на їх імідж. Водночас, не завжди ці дії відповідають реальним потребам зацікавлених сторін. Саме необхідність врахування інтересів стейкхолдерів стала основою ідеї щодо розроблення простої та зрозумілої для користувачів системи показників корпоративної соціально-екологічної відповідальності. Метою дослідження стало формування науково-методичних підходів до визначення індикаторів корпоративної соціально-екологічної відповідальності, які враховують запити його основних груп стейкхолдерів, та формують загальне бачення на шляху до формулювання стратегії розвитку підприємства та прийняття ефективних управлінських рішень при вирішенні соціальних, економічних та екологічних проблем. В результаті дослідження було розроблено комп'ютерну програму CSLinked, яка дозволяє аналізувати показники корпоративної соціальної відповідальності підприємств з урахуванням потреб зацікавлених сторін та забезпечує самооцінку компанії за трьома групами показників - економічним, соціальним та екологічним.

Ключові слова: корпоративна соціально-екологічна відповідальність, індикатор, прийняття управлінських рішень, підприємство, стейкхолдери, стратегія.

JEL Codes: D81, M14, Q56

Tables: 3; References: 15

Language of the article: English 
Лimepamypa

1. Okpara, J. O. \& Idowu, S. O. Corporate Social Responsibility Challenges, Opportunities and Strategies for 21st Century Leaders. Springer-Verlag Berlin Heidelberg. 2013. 315 p.

2. Bowen, H. R. Social Responsibilities of the Businessman. Harper \& Row: N. Y. 1953.

3. Davis, $K$. Can business afford to ignore social responsibilities? California Management Review. 1960. № 2 (3). Vol. 2. P. 70-76.

4. Carroll, A. B. Corporate social responsibility: Evolution of definitional construct. Business and Society. 1999. № 38 (3). P. 268-295.

5. Корнійчук, Л., Шевчук, В. Сталий розвиток і глобальна місія України. Економіка Украйни. 2009. № 4. C. 4-13.

6. Vasilieva, T. A., Lieonov, S. V., Makarenko, I. A. \& Sirkovska, N. Sustainability information disclosure as an instrument of marketing communication with stakeholders: markets, social and economic aspects. Marketing and Management of Innovation. 2017. № 4. P. 350-57. http://doi.org/10.21272/mmi.2017.4-31 (дата звернення 18.05.2020).

7. Sotnyk, I., Shvets, I., Momotiuk, L., \& Chortok, Y. Management of Renewable Energy Innovative Development in Ukrainian Households: Problems of Financial Support. Marketing and Management of Innovations. 2018. № 4. P. 150-160. http://doi.org/10.21272/mmi.2018.4-14 (дата звернення 18.05.2020).

8. Chortok, Yu. V., Yevdokymova, A. V., Zachko, O. B., Yevdokymov, A. V., Miroshnichenko, O. V. Financial aspects of stakeholders cross-sector partnership in implementation of communities sustainable development projects. Financial and credit activity: problems of theory and practice. 2019. Vol. 3. No. 30. P. 517-525. URL : http://fkd.org.ua/article/view/179927 (дата звернення 18.05.2020).

9. Бондар, А. В., Смоленніков, Д. О. Розроблення механізму партнерства влади, бізнесу та громади для реалізації еколого-орієнтованих проектів. Вісник Сумського державного університету. Серія: Економіка. 2016. № 4. С. 21-27. URL : http://nbuv.gov.ua/UJRN/VSU_ekon_2016_4_5 (дата звернення 18.05.2020).

10. Chortok, Yu., Yevdokymova, A., Serpeninova, Yu. Formation of the mechanism of corporate social and environmental responsibility of the trading company. Journal of environmental management and tourism. 2019. Vol. 9. No. 5. P. 1011-1018. http://doi.org/10.14505//jemt.9.5(29).13 (дата звернення 18.05.2020).

11. Чорток, Ю. В., Макаренко, І. О., Серпенінова, Ю. С. Прозорість компаній державного сектору України як основа задоволення інформаційних потреб стейкхолдерів в умовах сталого розвитку. Механізм регулювання економіки. 2017. № 4. 2017. С. 156-164.

12. Смоленніков, Д. О., Буряк, А. В. Специфіка інформаційних запитів стейкхолдерів у фінансовому секторі в умовах сталого розвитку. Механізм регулювання економіки. 2018. № 1. C. 53-61. http://doi.org/10.21272/mer.2018.79.04 (дата звернення 18.05.2020).

13. Hakobyan, N., Khachatryan, A., Vardanyan, N., Chortok, Y., \& Starchenko, L. The implementation of corporate social and environmental responsibility practices into competitive strategy of the company. Marketing and Management of Innovations. 2019. 2. P. 42-51.

14. Smolennikov, D., Kostyuchenko, N. The role of stakeholders in implementing corporate social and environmental responsibility. Business Ethics and Leadership. 2017. Vol. 1, No. 1, P. 55-62. http://doi.org/10.21272/bel.2017.1-07 (дата звернення 18.05.2020).

15. Сухотеріна, M. I. Механізм соціальної відповідальності у стратегії корпоративного управління машинобудівного підприємства: Дисертація на здобуття наукового ступеня кандидата економічних наук. Одеса : ОНПУ. 2015. 254 с. 